\title{
Doctors' deaths from covid-19 should be reported to the coroner
}

\author{
Raymond M Agius emeritus professor of occupational and environmental medicine \\ University of Manchester, Manchester M13 9PL, UK
}

The sad news at the time of writing (2 April 2020) that four doctors working in the NHS have died of covid-19 is aggravated by the fear that these might be the "tip of the iceberg" including nurses and other healthcare workers, as well as social care or other workers, who might yet succumb in the course of this terrible epidemic. ${ }^{1}$ These fatalities will undoubtedly cause speculation about whether, or to what extent, occupational exposure was responsible for an increase in the risk of contracting covid-19 and of dying from it. In due course occupational epidemiological research should give us some of the answers at a "population" level.

But what about these workers as individuals? What specific circumstances might have contributed to their deaths? A legally mandated mechanism might help answer these questions. Under UK law, doctors have a legal duty to notify a senior coroner of a death if "the registered medical practitioner suspects that the person's death was due to ... disease attributable to any employment held by the person." ${ }^{2}$ As the statutory instrument makes clear, the obligation to notify Her Majesty's coroner is triggered by a mere suspicion on behalf of the notifying doctor. After notification, the coroner would consider whether an inquest was warranted and might summon relevant witnesses to be questioned and to testify under oath. Notification to the coroner should not be viewed by doctors as merely a legal obligation; it is more than that. The coroner is entitled to make Reports on Action to Prevent Future Deaths. Like the proceedings of the coroner's court, these reports are a matter of public record and are valuable tools in ensuring that lessons are learnt, to reduce the risk of further tragedies.

Competing interests: None declared.

Seven days in medicine: 25-31 March 2020. BMJ 2020;369:m1288.32241757 2 UK Statutory Instruments. Notification of deaths regulations. 2019. http://www.legislation. gov.uk/uksi/2019/1112/made

Published by the BMJ Publishing Group Limited. For permission to use (where not already granted under a licence) please go to http://group.bmj.com/group/rights-licensing/ permissions 